\title{
Influence of phyllosilicate mineral assemblages, fabrics, and fluids on the behavior of the Punchbowl fault, southern California
}

\author{
John G. Solum, Ben A. van der Pluijm, and Donald R. Peacor \\ Department of Geological Sciences, University of Michigan, Ann Arbor, Michigan, USA \\ Laurence N. Warr \\ Geologisch-Palaeontologisches Institut, University of Heidelberg, Ruprecht-Karls-Universität, Heidelberg, Germany \\ Received 5 March 2002; revised 16 December 2002; accepted 24 January 2003; published 6 May 2003.
}

[1] The Punchbowl fault is an ancient segment of the San Andreas System that was active between 1 and $4 \mathrm{Ma}$ and exhumed from a depth of 2-4 km, thereby providing the opportunity to study processes along the top of the seismogenic zone of today's San Andreas fault. X-ray diffraction, X-ray texture goniometry, and scanning and transmission electron microscopy data characterize the detailed microstructural and chemical changes that occurred along the Punchbowl fault and address the importance of mineral transformations, rock fabric, and fluid activity on the hydromechanical behavior of the fault zone. On the basis of bulk and clay fraction X-ray analyses, the fault rocks have mineral assemblages that are distinct from the protolith, indicating that mineral reactions have occurred. However, microstructural observations show that many of the changes in mineral assemblages occurred after the cessation of faulting. Moreover, measures of phyllosilicate fabrics across the Punchbowl fault from X-ray goniometry are uniformly weak, and so phyllosilicate-induced permeability anisotropy in the zone was small. This absence of fabrics limits the effectiveness of fluid focusing along the fault, although some anisotropy may have been imparted by compartmentalization of the fault zone by occasional clay shears. Together these observations indicate that neither clay growth nor fabric-imposed fluid focusing appeared to have played a significant role during strike-slip faulting and cataclasite formation, which suggests that fault-weakening mechanisms that rely on clay growth and elevated fluid pressure cannot be applied to the Punchbowl

fault. INDEX TERMS: 3625 Mineralogy and Petrology: Descriptive mineralogy; 8159 Tectonophysics: Rheology — crust and lithosphere; 8030 Structural Geology: Microstructures; 7209 Seismology: Earthquake dynamics and mechanics; KEYWORDS: San Andreas fault system, Punchbowl fault, phyllosilicates, fault behavior, overprinting

Citation: Solum, J. G., B. A. van der Pluijm, D. R. Peacor, and L. N. Warr, Influence of phyllosilicate mineral assemblages, fabrics, and fluids on the behavior of the Punchbowl fault, southern California, J. Geophys. Res., 108(B5), 2233, doi:10.1029/2002JB001858, 2003.

\section{Introduction}

[2] The Punchbowl fault, located on the northeastern side of the San Gabriel Mountains in southern California (Figure 1), was an active strand of the San Andreas system from 1 to 4 Ma. The fault accommodated $\sim 40 \mathrm{~km}$ of right-lateral displacement [Dibblee, 1987] and was exhumed from a loosely constrained depth of $2-4 \mathrm{~km}$, based on the thickness of the stratigraphic sequence overlying the faulted Punchbowl formation [Chester and Logan, 1986; Dibblee, 1968]. The Punchbowl fault also accommodated some amount of dip slip associated with the uplift of the San Gabriel Mountains as indicated by fault-related folds in the Tertiary Punchbowl Formation adjacent to the fault [Dibblee, 1987]. As such it provides the opportunity to study

Copyright 2003 by the American Geophysical Union. 0148-0227/03/2002JB001858\$09.00 rocks that were involved in faulting at depth, and may serve as an analog for the modern San Andreas fault at shallow depths (above $4 \mathrm{~km}$ ). Assuming a geothermal gradient of $30^{\circ} \mathrm{C} / \mathrm{km}$ (similar to the value reported for the Cajon Pass borehole by Lachenbruch and Sass [1988]) and a bulk density of $2400 \mathrm{~kg} / \mathrm{m}^{3}$ (the value used by Vincent and Ehlig [1988] for Cajon Pass) the temperature was between 60 and $120^{\circ} \mathrm{C}$, and the lithostatic pressure was $\sim 45-95 \mathrm{MPa}$ $(0.45-0.95 \mathrm{kbar})$. The protolith in the study area is composed of Precambrian gneissic rocks and Mesozoic intrusives to the southwest of the fault and Tertiary sandstones and conglomerates (The Punchbowl and San Francisquito Formations) to the northeast (Figures 1 and 2).

[3] Similar to previous studies in the region, the fault zone at this location consists of ultracataclasite bound by less intensely deformed cataclasite. The Precambrian and Mesozoic protolith grades into an $\sim 0.5$-m-thick zone of green rock with cataclasite bands and a foliation that 


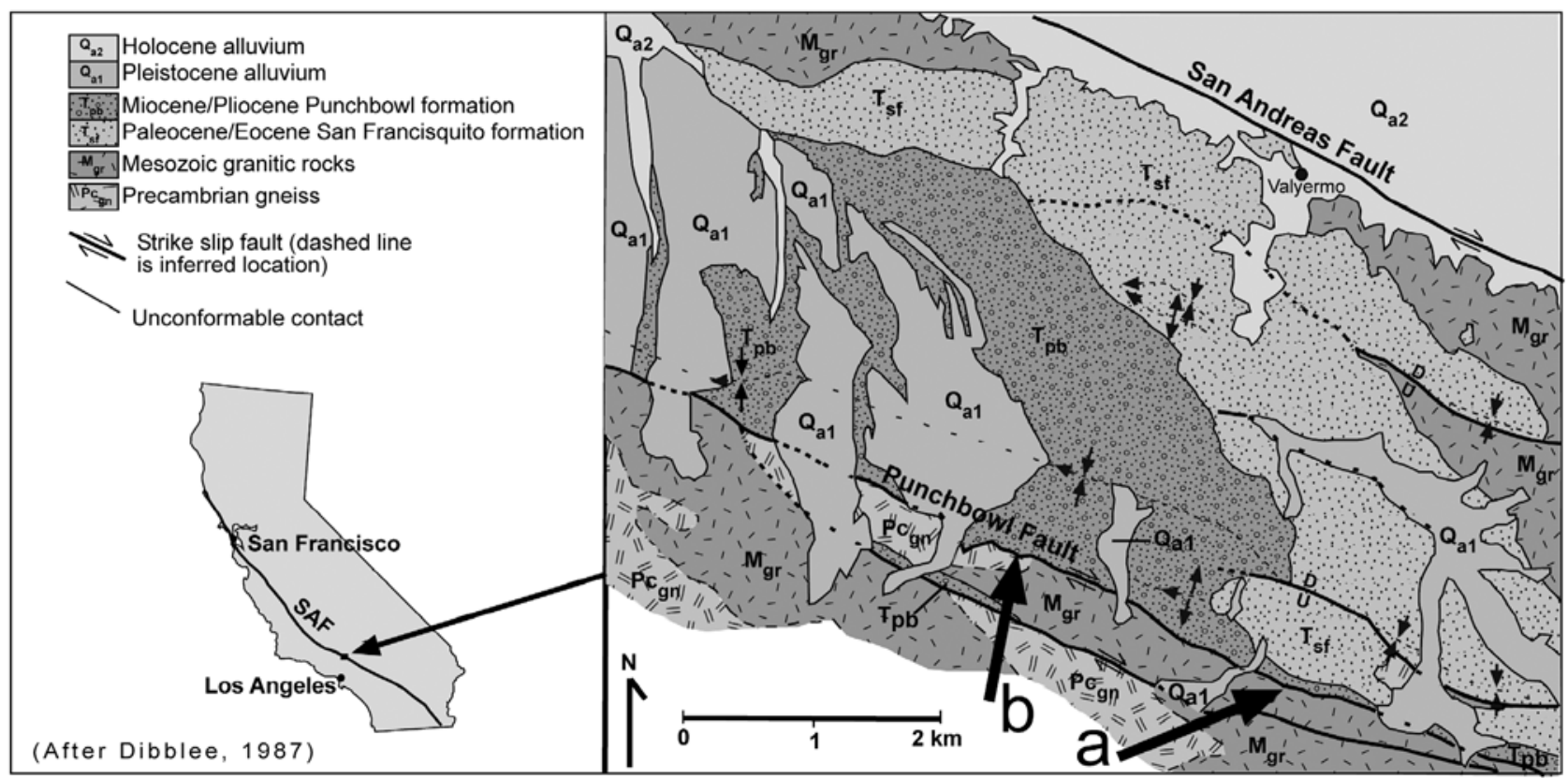

Figure 1. Location and geologic map of study area. SAF denotes the trace of the San Andreas fault. The sample location is marked on the geologic map by the arrow labeled "a," while the site examined by Chester and Logan [1986] and Chester and Chester [1998] is shown by the arrow labeled "b." At this location the fault accommodated $\sim 35 \mathrm{~km}$ of displacement between 1 and $4 \mathrm{Ma}$ and was exhumed from a depth of $2-4 \mathrm{~km}$.

becomes more pronounced further into the fault zone. This zone, hereafter referred to as the crystalline cataclasite zone due to its relationship to the crystalline protolith, grades into a red/purple/brown zone of ultracataclasite generally 0.75 $1.0 \mathrm{~m}$ thick, which in turn grades into generally white, coarser material filled with ultracataclasite bands between $\sim 0.5$ and $10.0 \mathrm{~cm}$ wide. This zone, hereafter referred to as the foliated cataclasite zone, is $\sim 4 \mathrm{~m}$ thick, and grades into cataclastically deformed Punchbowl formation. At this exposure, boundaries between components of the fault zone are not as sharp as observed elsewhere along the fault. Chester and Logan [1986] and Chester and Chester [1998], who examined the fault to the northwest of this study area (Figures 1 and 2) where the same rock types are juxtaposed, observed a discrete layer of ultracataclasite, in contrast to the gradational contacts observed in this study. The ultracataclasite is likely where the majority of displacement was accommodated at both sites.

[4] Several observations indicate that many faults, and the San Andreas fault in particular, may be weak, failing under stresses that are approximately an order of magnitude smaller than those predicted by laboratory experiments [e.g., Kanamori and Anderson, 1975; Lachenbruch and Sass, 1980; Mount and Suppe, 1987; Zoback, 2000; Chéry et al., 2001; Ruff, 2002], although, e.g., Scholz [1990, 2000] has proposed explanations compatible with strong-fault behavior. This study focuses on mineralogical relations and fabric of fault rocks with emphasis on phyllosilicates because several mechanisms that have been proposed to explain fault behavior appeal to the role of phyllosilicates in

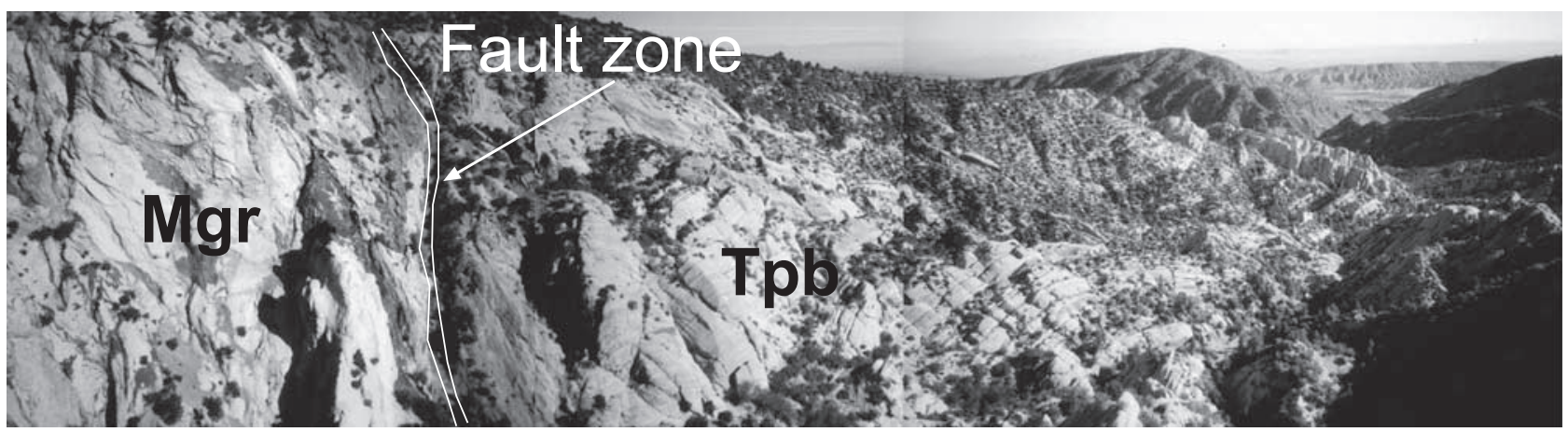

Figure 2. Photographic panorama of the Punchbowl fault $\sim 1 \mathrm{~km} \mathrm{NW}$ of the study site. At this location the same lithologies are photogenically juxtaposed as at the study site. Mgr, Mesozoic granitic crystalline rocks; Tpb, Tertiary Punchbowl formation. This is the location studied by Chester and Logan [1986] and Chester and Chester [1998]. 
fault rocks [e.g., Rice, 1992]. Changes in phyllosilicate fabric across the Punchbowl fault zone would provide information about the permeability structure of the fault, which relates to elevated fluid pressure, whereas mineralogical reactions may produce relatively weak fault material [e.g., Wang, 1984].

[5] Elevated fluid pressure has long been proposed as a mechanism that allows faults to behave weakly [e.g., Hubbert and Rubey, 1959; Rice, 1992] or driving fault rupture [e.g., Sibson, 1990], although others suggested that dynamic weakening mechanisms may be responsible for weak-fault behavior, for example the acoustic fluidization of Melosh [1996]. The mechanism that confines high-pressure fluids to the region of the fault where earthquakes nucleate, however, is not well understood. Although significant progress on the problem of hydraulic fracturing has been made [Rice, 1992], which can explain how fluid pressure could be higher in the fault zone as a hole relative to protolith, the mechanism by which fluids can be localized to the seismogenic region of a fault zone (i.e., the fault core, or ultracataclasite) remains unclear. The core of a fault, the region where earthquakes nucleate and where most of the displacement is accommodated, is typically finer grained, and has lower permeability than surrounding rocks, which are generally intensely fractured and have a comparatively higher permeability (the damage zone of Caine et al. [1996] and Chester and Logan [1986]). A definitive mechanism that would keep fluids in the fault from escaping from the fault core through that fractured rock is unknown, but scenarios have been proposed. Clays are common constituents of fault rocks, and permeability anisotropy resulting from a preferred orientation of clay grains and/or the development of fault-parallel shears within gouge may be the mechanism by which fluids are focus along faults. Experiments with natural [e.g., Evans et al., 1997; Morrow et al., 1984] and synthetic gouges [e.g., Zhang et al., 1999; Zhang and Cox, 2000] support the observation that permeability anisotropy exists in samples of pure clay gouge and samples containing clay shears. Evans et al. [1997] measured permeability parallel and perpendicular to the fault plane in samples from the fault core, damage zone and protolith of thrust faults from the Washakie Range in Wyoming. They found that permeability anisotropy existed in fault core samples, although its magnitude decreased with increasing effective stress, which they attributed to the presence of fault-parallel fractures. Zhang et al. [1999] found that the permeability anisotropy in synthetic mica gouge decreased with increasing shear, and that it was possible to develop a maximum permeability anisotropy of one order of magnitude, although this was greater in samples of quartzofeldspathic gouge due to the development of finer-grained low-permeability regions that formed due to shear localization. Faulkner and Rutter [2001] calculated that permeability anisotropy of three orders of magnitude is required for overpressure to develop in a fault zone $\sim 1 \mathrm{~km}$ wide. The requirement that preferred orientation in clays imparts permeability anisotropy is not yet supported by quantitative studies of phyllosilicate fabrics in natural fault rocks, which is one of the goals of this study. Moreover, mineral assemblages and microstructure of fault rocks and protolith have been described in previous studies, but the timing of formation of these features remains uncertain. The latter is critical for understanding the mechanical role of clays in fault rocks, which is examined in this study through microstructural analyses.

\section{Previous Work}

[6] Chester and Logan [1986] studied the Punchbowl fault slightly northwest of the study area of this paper. They noted a distinct "gouge" layer ranging from $5 \mathrm{~cm}$ to $1 \mathrm{~m}$ (average of $30 \mathrm{~cm}$ ), in contrast to the exposure of the Punchbowl fault examined in this study. Chester and Logan [1986] found that the gouge was slightly depleted in quartz, illite, and laumontite with respect to the Punchbowl formation, and enriched in smectite.

[7] Chester and Chester [1998] noted the presence of a layer of ultracataclasite with sharp boundaries with adjacent fault rocks. They found that the ultracataclasite is depleted in potassium feldspar, plagioclase feldspar (to a minor extent), illite, kaolinite, and laumontite (with respect to the Punchbowl formation), and is enriched in smectite, clinoptillolite and analcime. They determined that the ultracataclasite was composed of $\sim 75 \%$ grains that were less than $10 \mu \mathrm{m}$ in size, $20 \%$ veins and vein fragments, and 5\% single-crystal porphyroclasts, and noted that the ultracataclasite occurred in two distinct colors, one in contact with the crystalline protolith, and one the Punchbowl formation, and that no mixing occurred between the two ultracataclasites. The presence of synfaulting fluids was indicated by the presence of mutually crosscutting veins and shear bands within the ultracataclasite.

[8] Schulz and Evans [1998] studied the Punchbowl fault $\sim 20 \mathrm{~km}$ southeast of the study area of this paper where two strands of the fault juxtapose crystalline basement rocks. They found that the fault in that area consists of an $\sim 10-\mathrm{cm}-$ thick gouge-filled core and a 15-cm-thick zone of brecciated rock. These authors inferred that synfaulting fabrics, which were preserved as deformation-related fabrics, were observed in thin sections, indicating that some fault-related textures had been preserved during exhumation. The fault rocks along the northeastern strand were composed of quartz, albite, clinochlore, \pm epidote, and the protolith quartz, albite, muscovite, \pm actinolite \pm epidote \pm hornblende.

\section{Sample Preparation and Analysis}

[9] X-ray diffraction (XRD) analyses were conducted on a Scintag $\theta-\theta$ diffractometer using $\mathrm{CuK} \alpha$ radiation, and samples were scanned from 4 to $50^{\circ} 2 \theta$ at a rate of $0.25^{\circ}$ min. All samples were first crushed by placing them in a shatter box for 15-30 s. A portion of the bulk sample was retained for X-ray analysis, and the remainder was suspended in distilled water and ultrasonically treated to further disaggregate the sample. Following the ultrasonic treatment the $<4-\mu \mathrm{m}$ size fraction (the clay fraction) was extracted from the samples by repeatedly centrifuging the disaggregated mixture until little or no material remained in suspension. Slides of the bulk and clay fractions were prepared by drying clay/water and clay/acetone suspensions on glass slides. Because clay minerals have a platy habit this procedure results in a sample in which the clay particles are aligned parallel to the glass slide. This aids the identification of clay minerals on X-ray powder diffraction 
patterns as the intensity of 001 peaks is increased. Air-dried samples were analyzed and then placed in a chamber containing ethylene glycol in order to replace interlayer water molecules in the clays with molecules of ethylene glycol. This procedure causes swelling clays to expand, and the resulting increase in $d$ values allows swelling clays to be distinguished from nonswelling phyllosilicates, which are unaffected by glycolation. Peak areas and widths on X-ray powder diffraction patterns, used in measurements of mineral concentrations and crystallinity, were calculated using background-stripped powder patterns with the program MacDiff 4.2.5.

[10] Relative changes in the concentration of mineral phases was determined through changes in the relative area of various peaks on X-ray powder diffraction patterns. The peaks that were used were chosen based on a lack of overlap with peaks of other minerals. The peaks used were clinochlore $001(14.3 \AA)$, chlorite/smectite 001/001 ( $x>14.3 \AA$, varies as a function of the concentration of smectite), illite/ muscovite 001 (10 ̊), illite/smectite 001/001 ( $x>10 \AA$ upon glycolation, varies as a function of the concentration of smectite), laumontite 110 (9.5 ̊), quartz 100 (4.259 ̊), albite $\overline{2} 01$ (4.03 $\AA$ ), orthoclase 040 (3.25 ̊), and calcite 104 (3.035 ̊).

[11] Crystallinity was calculated using peak widths, which are inversely related to the size of the X-ray scattering domains (crystallites) in a sample. A recent description of the history of crystallinity calculations and their geologic applications is provided by Merriman and Peacor [1999]. A broader peak indicates a smaller crystallite size and therefore a higher crystallinity index. The crystallinity of a sample is the result of several competing processes. The crystallinity index will be decreased through any process that increases the package thickness of phyllosilicates, particularly mineral growth that increases the size of existing mineral grains or the coalescence of subgrains into single grains. The crystallinity index will increase in response to processes that result in a decrease in package thickness, such as the proportion of the number of defects caused by stress, deformation intense enough to cause single crystals to be divided into subgrains, or by neoformation of smaller crystals. Crystallinity therefore is a function of several factors including temperature, strain, and fluid activity and composition [Merriman and Peacor, 1999; Essene and Peacor, 1995]. It is generally not possible to determine which of these individual factors is responsible for the changes in crystallinity using XRD.

[12] For X-ray texture goniometry (XTG), scanning electron microscopy (SEM), and transmission electron microscopy (TEM), oriented samples were vacuum-impregnated with a low-viscosity, low-shrinkage, low-temperature resin. Once cured, samples were cut using an oil-lubricated saw to prevent degradation of swelling clays. Samples were cut perpendicular to slip surfaces or foliations in an effort to ensure that the cut face would be perpendicular to the clay fabric so that the $c$ axis of phyllosilicates would be subparallel to the cut face, which is required in order for $d$ values to be measured from TEM lattice fringe images and selected area electron diffraction (SAED) patterns, as well as for XTG. Two 200-400 $\mu \mathrm{m}$ sections, one for XTG and one for SEM/TEM, were then cut from the samples and were attached to glass slides using sticky wax, which has a melting point of $\sim 80{ }^{\circ} \mathrm{C}$, so that the samples could later be removed from the glass slide, after which the samples were polished in order to ensure that the sample face would be smooth.

[13] After polishing the XTG samples were removed from the slides and placed on custom-made aluminum holders, which were then placed in a modified singlecrystal X-ray diffractometer with a Mo source $(\lambda=$ $0.7107 \AA$ ) and analyzed after the method of van der Pluijm et al. [1994]. A bulk XRD analysis was performed in order to identify the mineral phases present in the sample, and the detector was then rotated to the value of $2 \theta$ that corresponded to the Bragg diffraction angle of the 001 and/or 002 plane of the phyllosilicates that were identified during the bulk scan. The sample was then rotated through approximately 1300 positions, and the intensity of the diffracted beam was recorded at each position. The diffracted beam intensities were plotted in spherical projection and contoured as multiples of a random distribution (MRD), a standard statistical measure of the relative randomness of a distribution. If a preferred orientation exists, the diffracted beam intensities cluster, and the intensity of that clustering (referred to as the fabric intensity as opposed to the diffracted beam intensity) is a function of the relative perfection of the fabric.

[14] X-ray texture goniometry (XTG) provides quantification of phyllosilicate fabrics [van der Pluijm et al., 1994]. Because XTG is based on measurements of diffracted X-ray beams, it measures crystallographic preferred orientation, which directly corresponds to grain shape-preferred orientation in phyllosilicates. The fabric intensity provides a measure of the amount of phyllosilicate-induced permeability anisotropy that exists, because fabrics with greater intensities will have greater permeability anisotropies (permeability will be greater parallel to the fabric than perpendicular to it).

[15] Multiple XTG analyses, each analysis covering $\sim 1 \mathrm{~mm}^{2}$ of a thick section, were used to quantify the phyllosilicate fabric. There is no lower grain-size limit with XTG; however, the effectiveness of XTG decreases with increasing grain size. As the grain size of the phyllosilicates approaches the size of the beam the number of analyzed grains decreases, and so the analyses cease to be representative of the entire phyllosilicate population. This can be countered by conducting multiple XTG analyses and averaging the results.

[16] Scanning electron microscopy constrains interpretations of X-ray data by providing images of the mineral assemblages and fabrics measured through X-ray analysis. Scanning electron microscopy (SEM) will provide information about the $\mathrm{mm}$ to $\mu \mathrm{m}$ scale mineralogical distribution and microstructure. Qualitative energy-dispersive spectra (EDS) analyses provide information about the distribution of mineral species within a sample. These data, combined with any crosscutting relationships observed in back-scattered electron (BSE) or secondary electron (SE) images, can provide information about the relative timing and nature of episodes of mineralization. SEM was also used to determine locations within a sample for additional transmission electron microscopy.

[17] Once TEM locations on sticky wax slides were identified, aluminum washers $2 \mathrm{~mm}$ in diameter were glued 


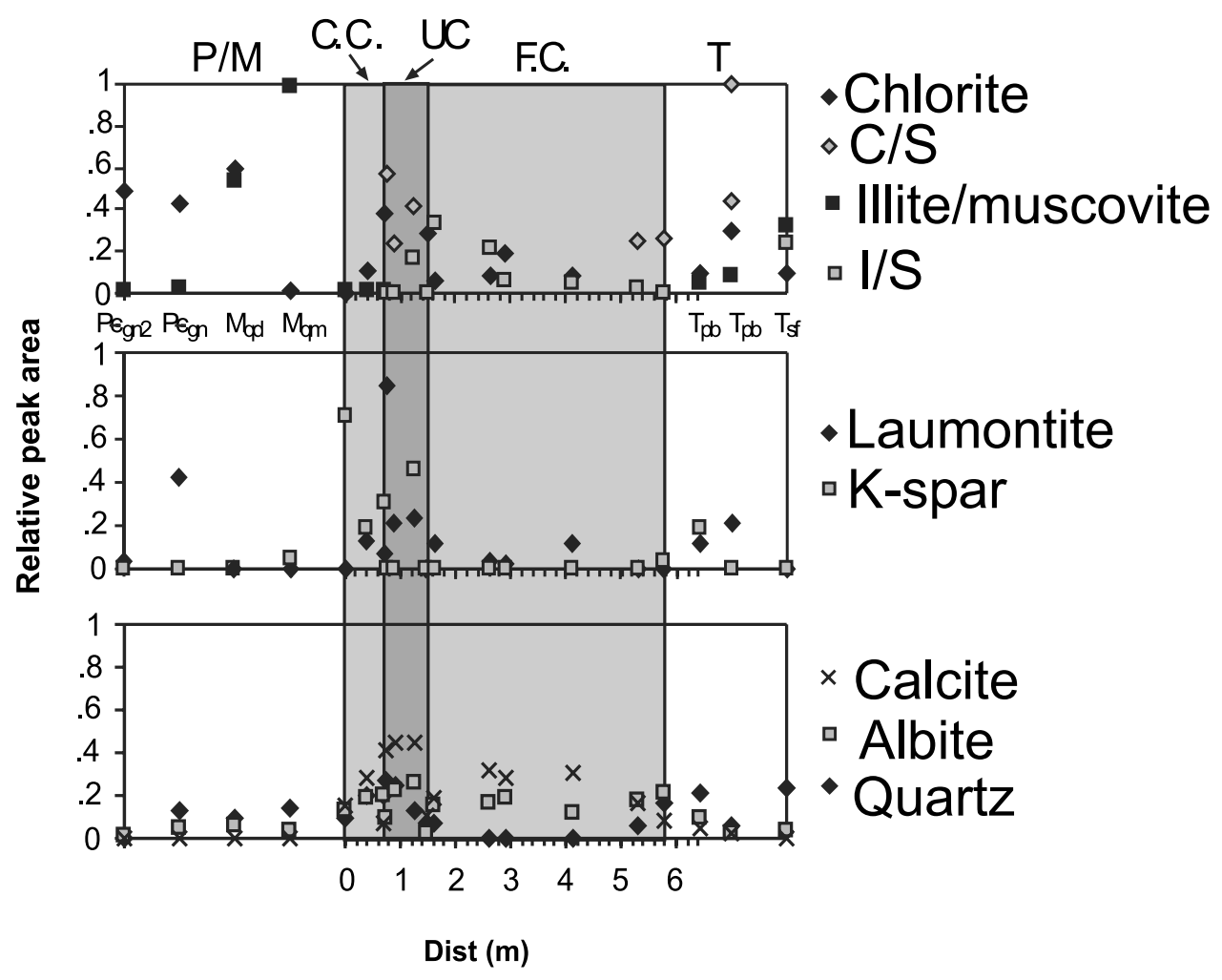

Figure 3. Mineral assemblages along a NE-SW traverse across the Punchbowl fault zone based on semiquantitative X-ray diffraction. The XRD values are shown an a schematic cross section through the fault zone with zero arbitrarily set to the contact between Precambrian/Mesozoic protolith and the fault zone. The labeled zones are Precambrian/Mesozoic protolith (P/M), crystalline cataclasite (C.C.), ultracataclasite (UC), foliated cataclasite (F.C.), and Tertiary protolith (T). Samples of protolith formations that were not encountered along the traverse but that are exposed in the area are placed on the far right and far left of the diagram. For the Precambrian formations these include a quartz-rich gneiss (Pघgn), and a hornblende/biotite gneiss (Pघgn2). For the Mesozoic formations these include a quartz monzonite (Mqm) and a quartz diorite (Mqd). For the Tertiary formations these include the Punchbowl formation (Tpb) and the San Francisquito formation (Tsf). The changes in mineral assemblages across the fault zone indicate that mineral reactions occurred but provide no information on the timing of those reactions.

to the sample. The areas with washers were then removed using a razor blade and placed in an argon ion mill and thinned until electron transparent in the TEM. Samples with swelling clays were impregnated with LR White resin, which prevents collapse of smectite interlayers under the electron beam. Samples were analyzed with a Phillips TEM with a detector allowing quantitative energy dispersive spectra (EDS) to be collected.

[18] Transmission electron microscopy (TEM) was used to obtain microstructural and quantitative microchemical data through the use of imaging, EDS analyses and selectedarea electron diffraction (SAED). TEM observations were used to constrain interpretations made from data obtained using XRD techniques by providing direct images of the analyzed materials. SAED patterns provide information about the crystallographic structure of mineral grains, such as the ordering of the stacking sequences of phyllosilicates. The spacings of (001) reflections characterize specific phyllosilicates, and the nature of (hk0) reflections provide information about stacking. Streaking of (hk0) reflections indicates mixed layering or disordered stacking, whereas discrete $(\mathrm{hk} 0)$ reflections are indicative of ordered polytypes of a single type of layer.

\section{Results}

\subsection{X-Ray Diffraction}

[19] Figure 3 shows that the concentration of chlorite is greatest in the Precambrian and Mesozoic protolith, and least in the ultracataclasite, where the concentration of chlorite/smectite is greatest. Chlorite/smectite is also present in the San Francisquito formation where tosudite (interlayered chlorite/montmorillonite) and saponite (a trioctahedral smectite) occur. The concentration of illite/muscovite is greatest in Precambrian and Mesozoic protolith (muscovite) and in the Tertiary Punchbowl and San Francisquito formations (illite), while the concentration of illite/smectite is greatest in the foliated cataclasite near the ultracataclasite and is only present outside of the fault zone in the San Francisquito formation. There is no pattern to the distribution of laumontite across the fault zone, with the exception of one very large value in the ultracataclasite, and similarly 


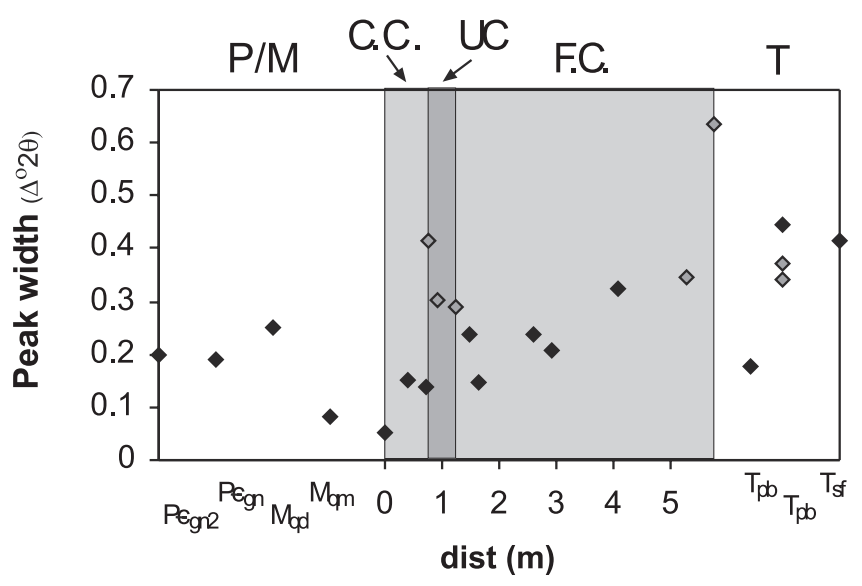

Figure 4. Variation in the width of the 001 chlorite peak (solid symbols) or 001/001 chlorite/smectite peak (gray symbols) from XRD patterns across the fault zone. The abbreviations and symbols used are the same as on Figure 3. The ultracataclasite is characterized by broad peaks, which are due to a large number of smectite interlayers in those samples. As discussed in the text, the chlorite/smectite in the ultracataclasite is interpreted as the result of postfaulting mineralization based on TEM observations.

there is no pattern to the distribution of potassium feldspar. The concentration of quartz is greatest in the ultracataclasite and Tertiary formations, and is generally small in the foliated cataclasite. Fault rocks are enriched in albite and calcite relative to protolith. Hornblende was present in samples of a Precambrian gneiss and Mesozoic quartz diorite, as well as in one sample of the Punchbowl formation near the edge of the foliated cataclasite. Analcime was also found in one sample of the Punchbowl formation, but was not found in any other sample.

[20] Figure 4 depicts variation in peak width of the 001 chlorite or 001 chlorite/smectite peak, and therefore variations in chlorite crystallinity, across the fault zone. The crystallinity is greatest for the ultracataclasite and for the contact between the Punchbowl formation and the foliated cataclasite. This is due to the large number of smectite interlayers in those samples. There is no other pattern to the distribution of crystallinity.

[21] The relative area of chlorite 001,002 , and 004 peaks across the fault zone is shown in Figure 5. The ratio of the $002 / 001$ and $004 / 001$ peak is greater in fault rocks than in protolith, indicating that there is some difference between chlorite in and out of fault rocks. Relative peak areas of samples from fault rocks more closely match those of ferroan clinochlore, while those of samples from the protolith more closely match those of clinochlore. Therefore the chlorite in fault rocks is likely enriched in iron relative to the chlorite in protolith.

\subsection{X-Ray Texture Goniometry}

[22] The intensity of the chlorite fabric across the Punchbowl fault is uniformly weak (Figure 6), indicating that there is no fabric defined by preferentially oriented chlorite grains. The fabric is generally poor in the ultracataclasite, although it is slightly greater near the boundary with the foliated cataclasite zone. The fabric is best developed toward the middle of the foliated cataclasite zone, and becomes smaller toward the contacts with both the ultracataclasite and the Punchbowl formation. The

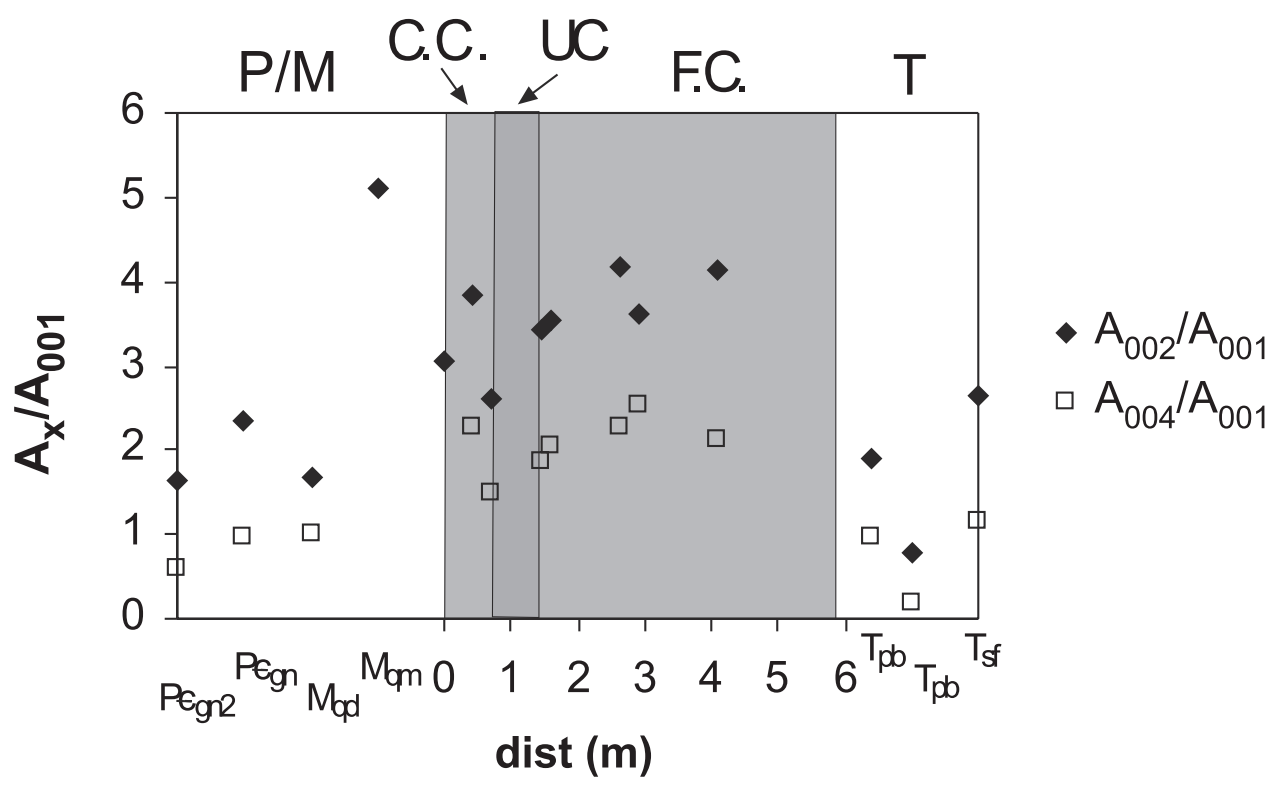

Figure 5. Variation in the relative areas of the 001, 002, and 004 chlorite peaks from XRD patterns across the fault zone. The abbreviations and symbols used are the same as on Figure 3. The value of 002/ 001 and $004 / 001$ is greater in fault rocks than in protolith, which is most likely due to greater amounts of iron in the fault rock samples. As discussed in the text the chlorite in protolith (low 002/001 and 004/001) is interpreted as detrital and the chlorite in the fault rocks (high 002/001 and 004/001) is interpreted as having formed during faulting through the alteration of protolithic chlorite. On the basis of TEM observations rare grains of protolithic chlorite are preserved in fault rocks (Figures 8a and 8b). 


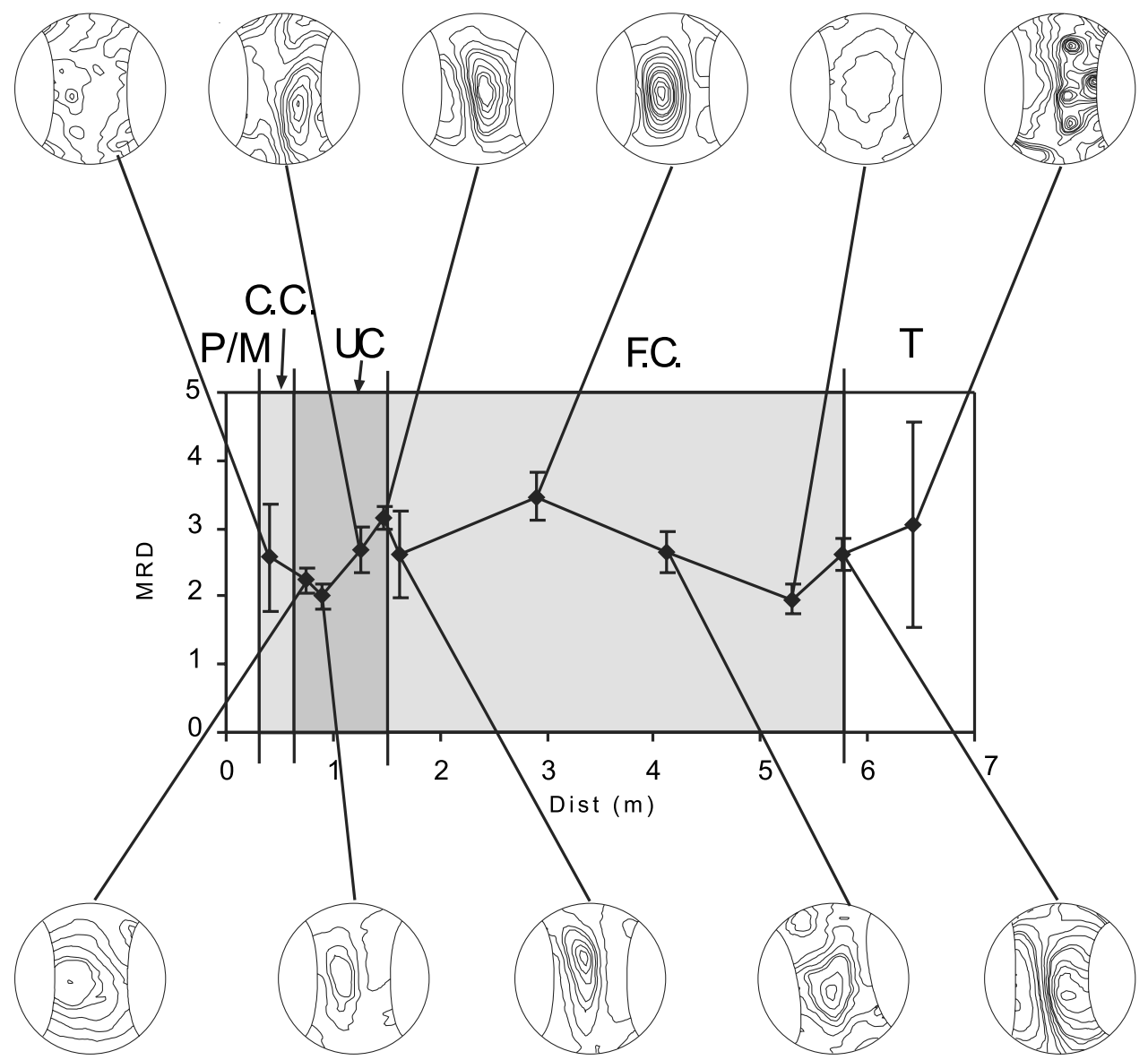

Figure 6. Examples of X-ray texture goniometry pole figures from a traverse across the Punchbowl fault zone. Abbreviations are the same as those used in Figure 3. Contour interval is $0.25 \mathrm{MRD}$. Error bars are \pm one standard deviation. Pole Figures have been rotated so that the center of the distribution is in the center of the plot and so do not reflect the orientation of the fabrics in the outcrop.

large uncertainty in the fabric intensity measurement within the cataclastically deformed Punchbowl formation is due to the large grain size in that region. The small range in values illustrates that no significant change in phyllosilicate fabric is observed in the fault rocks. The fabric intensity is not controlled by phyllosilicates concentration (i.e., samples with small phyllosilicates concentrations do not have the weakest fabrics) as there is no relationship between fabric intensity and phyllosilicates concentration. This indicates that the chlorite in the fault zone, even where relatively abundant does not have a great degree of preferred orientation.

\subsection{Scanning Electron Microscopy}

[23] Back-scattered electron (BSE) images reveal that cataclastic textures dominate the samples, and that there are multiple generations of cataclasite within the foliated cataclasite, indicating multiple slip events. In the foliated cataclasite chlorite generally occurs in discrete anastomosing shears, and these shears are cut by zeolite-bearing cataclasite, where the zeolite occurs as individual grains as opposed to veins. This indicates that the chlorite shears are older than the zeolite-bearing cataclasite (Figure 7). The chlorite shears were formed during faulting, although it is not possible to determine if the chlorite is composed of

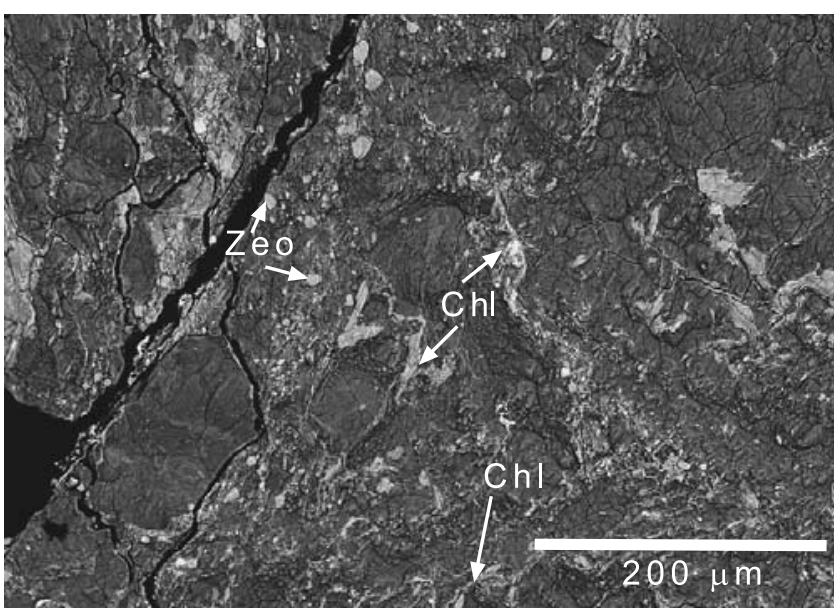

Figure 7. Back-scattered electron images of fault rocks exhibiting characteristic cataclastic deformation. Zeolites are largely undeformed and euhedral, indicating that zeolite growth is postfaulting. Chlorite shear (chl) bearing cataclasite is cut by zeolite bearing cataclasite (zeo). 
reworked detrital material or is authigenic in origin, based on SEM data only (see below). The relative age of the zeolite is unclear, however, since it does not occur in deformed veins as along the San Gabriel fault as described by Evans and Chester [1995] it is considered to be postfaulting. The observation that the zeolite occurs as isolated grains suggests that it may be the product of replacement of preexisting grains (likely of plagioclase).

\subsection{Transmission Electron Microscopy}

[24] From TEM observations we can divide the trioctahedral and dioctahedral phyllosilicate population into three groups. Group I is characterized by relatively large, undeformed, sometimes altered grains of ordered polytypes of chlorite and muscovite (Figures 8a and $8 b$ ), group II is characterized by large grains of sometimes deformed grains of disordered polytypes of chlorite (Figures $8 \mathrm{c}$ and $8 \mathrm{~d}$ ) and illite (Figures 8e and 8f) both with smectite interlayers, and group III is characterized by delicate, "hairy" disordered grains of trismectite-rich interlayered chlorite/smectite (Figures $8 \mathrm{~g}$ and $8 \mathrm{~h}$ ). Zeolite, which occurs in pores between chlorite/smectite grains in the ultracataclasite (Figures 8c and $8 \mathrm{~d}$ ), indicates that zeolite mineralization postdates chlorite/smectite mineralization.

\section{Discussion}

[25] The field observations on the Punchbowl fault share similarities with earlier studies, but there are significant differences. The boundary between the ultracataclasite and the surrounding zones is not sharp but is gradational, and the $\sim 4$-m-wide cataclasite zone observed in this study is not as pronounced at other areas. These observations indicate that the strain localization inferred from other outcrops is not everywhere present. Such along-strike variation within the Punchbowl fault zone is not surprising as both modern and ancient members of the San Andreas system exhibit such variation [e.g., Evans and Chester, 1995].

[26] On the basis of microscopic analysis, the three phyllosilicate groups are interpreted as detrital (group I chlorite and muscovite), synfaulting authigenic (group II chlorite/smectite and group II illite/smectite), and postfaulting authigenic (group III chlorite/smectite) populations. Group I is considered to be detrital because of relatively large grain size and ordered polytypism, whereas group II is on occasion deformed and, most significantly, occurs in shears. The difference in polytypism between groups I and II indicates that disorder in group II is due, at least in part, to shearing of layers of group I chlorite and muscovite. Therefore group II chlorite/smectite formed through alteration of group I chlorite. Group III is associated with postfaulting authigenic mineralization because of the small grain size, lack of deformation, fibrous habit, and occupancy of void space (Figures $8 \mathrm{~g}$ and $8 \mathrm{~h}$ ). Group III is also recognizable by large peak widths on X-ray diffraction patterns (Figure 4), which, as discussed above, is due to the large number of smectite interlayers in those samples. Groups I and II can also be separated based on the relative areas of the 001,002 , and 004 chlorite peaks (Figure 5). Group I is equivalent to the samples where 002/001 and 004/001 are smaller (i.e., protolith), while group II is equivalent to the samples where those values are greater (i.e., fault rocks). As discussed

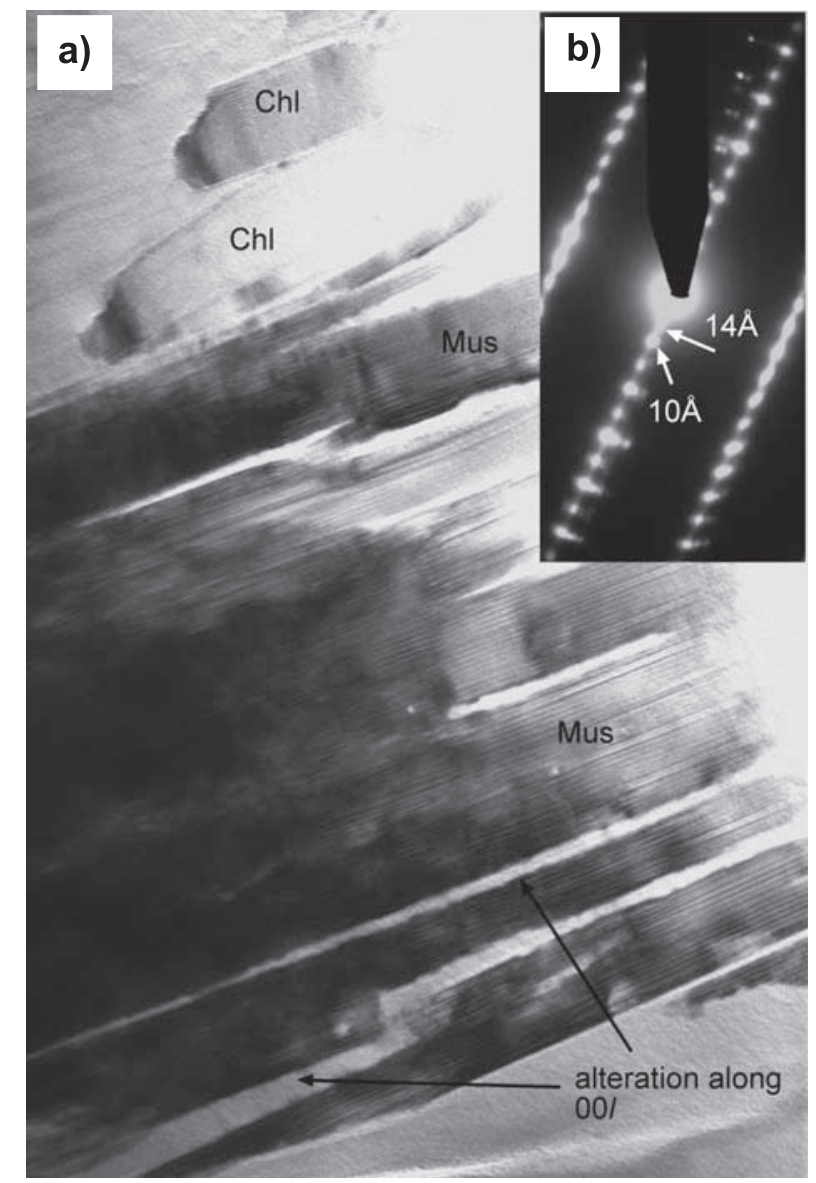

Figure 8. (a) TEM lattice fringe image and (b) SAED pattern of group I muscovite (Mus) and chlorite (Chl), considered to be detrital. The inset SAED pattern indicates that stacking along (001) is ordered (a characteristic of more mature phyllosilicates). Local alteration along 001 is present in the muscovite, likely resulting in the formation of smectite. The sample is from the foliated cataclasite. (c) Lattice fringe image and (d) SAED pattern of group II chlorite/trismectite (Chl-Sm) from the ultracataclasite. The streaked hkl reflections on the SAED pattern indicate that stacking along (001) is disordered (indicative of less mature phyllosilicates). The grain is ruptured, indicating that it is formed during faulting. This population is composed of deformed and altered protolithic grains (i.e., group I) and not neocrystallized grains because of its comparatively large grain size. The zeolite mineral laumontite (Lau) appears to have formed in pores between chlorite grains. Along with other observations this demonstrates that zeolite mineralization postdates group I and group II phyllosilicate growth. (e) Lattice fringe image and (f) SAED pattern for group II illite/ smectite (Il-sm) from the foliated cataclasite. Formation of group II illite/smectite occurred after formation of group II chlorite/trismectite because the illite/smectite grains are not ruptured. Qtz is quartz. (g) TEM lattice fringe image and (h) SAED pattern of representative Group III chlorite/smectite (chl-sm and sm) from the ultracataclasite, interpreted largely as postfaulting neocrystallization due to small grain size and fibrous habit. Alb is albite. The circular SAED pattern is indicative of random stacking, a characteristic of smectiterich phyllosilicates. This represents the latest stage of phyllosilicate mineralization. 

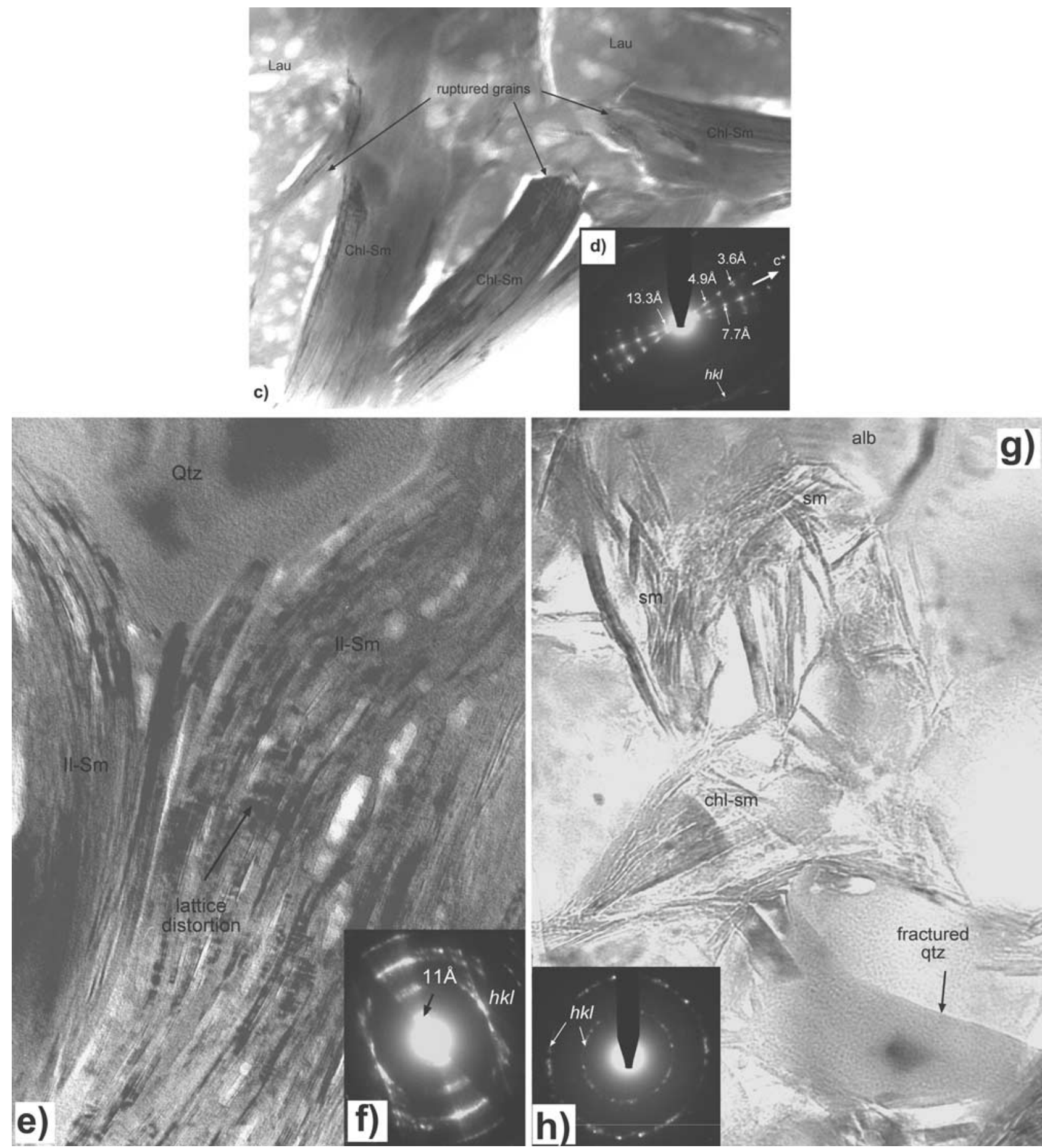

Figure 8. (continued)

above, these differences are likely due to variations in the amount of iron and magnesium contained in the samples with the protolithic samples more magnesium-rich. The observation that the ultracataclasite is enriched in chlorite/ smectite is similar to the finding of Chester and Logan [1986], who found that the ultracataclasite was enriched in smectite. This indicates that the ultracataclasite may be significantly overprinted by postfaulting neomineralization for much of the length of the Punchbowl fault. The ultra- cataclasite has been overprinted to a greater degree than the cataclasite, which reflects greater dissolution and recrystallization in the region of most intense deformation. As illustrated in Figure 8c, the group II chlorite/smectite mineralization in the ultracataclasite precedes zeolite mineralization, and likely during strike-slip faulting since the grain is ruptured. Chlorite and saponite have both been found in the Sancerre-Couy Deep Drill Hole [Beaufort and Meunier, 1994; Beaufort et al., 1997], at depths of $\sim 1-$ 
$2.5 \mathrm{~km}$ (D. Beaufort, Université de Poitiers, personal communication, 2002) demonstrating that those phases are indeed stable at depths near those at which the Punchbowl fault was active. Chlorite mineralization has also been observed in association with the active Nojima fault in Japan [Ohtani et al., 2000] to a depth of $\sim 2.5 \mathrm{~km}$, where it is interpreted as a result of prefaulting alteration of protolith, which is comparable to our group I chlorite.

[27] The postfaulting origin of the zeolite is indicated by SEM and TEM images that depict zeolite occurring in bands that cut chlorite-bearing rocks and its occurrence in pores in between chlorite and chlorite/smectite grains. Combined, the postfaulting origin of the zeolite, illite/smectite, and group III chlorite/smectite indicate that synfaulting features have been significantly overprinted.

[28] Zeolite formation is consistent with the observed changes in mineralogy in that the greatest proportions of quartz are associated with low concentrations of laumontite:

labradorite + dissolved silica $\rightarrow$ laumontite + albite

This reaction has also been proposed to account for the existence of laumontite along the nearby San Gabriel fault [Evans and Chester, 1995]. The association of laumontite with active and ancient fault zones is well known. Laumontite has been previously observed along the Punchbowl fault [Chester and Logan, 1986; Chester and Chester, 1998; Schulz and Evans, 1998], as well as along the Nojima fault [Ohtani et al., 2000] and in the borehole [James and Silver, 1988] and in outcrop [Vincent and Ehlig, 1988] at Cajon Pass near the San Andreas fault. Contrary to our findings, laumontite mineralization in all of these cases was interpreted as synfaulting due to the presence of brecciated laumontite veins. Laumontite growth generally represents one of the youngest episodes of mineralization along these faults, similar to the relative timing of zeolite mineralization in this study. Chester and Evans [1995] observed that in places along the San Gabriel fault veins of fine-grained laumontite and clays were found, and the small grain size of these veins illustrates the importance of using TEM to determine textural relationships at scales finer than possible using SEM. On the basis of the observation that laumontite veins were not affected by fault-related folding, Vincent and Ehlig [1988] concluded that laumontite mineralization represented a young episode of mineralization at Cajon Pass. Laumontite also commonly occurs as a fracture filling, and this is consistent with the claim that laumontite mineralization is a relatively near-surface phenomenon where fractures are more open than at depth. In the case of the Nojima fault [Ohtani et al., 2000] and at Cajon pass [James and Silver, 1988] laumontite has been inferred to have formed at depth based on pressuretemperature (P-T) calculations of the stability field of laumontite [e.g., Liou, 1971; Zen and Thompson, 1974] or the measured occurrence of laumontite in natural settings [e.g., Henley and Ellis, 1983]. These P-T diagrams and extrapolations from natural occurrences of laumontite are not readily applicable to these fault-related situations, however. The stability of laumontite is affected by the concentration of $\mathrm{CO}_{2}$ in pore water, water pressure relative to total pressure, as well as the presence of iron and magnesium [Liou, 1971]. The existence of neoformed chlorite/smectite in the Punchbowl fault (group III) also indicates that iron and magnesium were present in fluids that moved through the Punchbowl fault zone. The presence of $\mathrm{NaCl}$ in solution also appears to promote the formation of laumontite. While attempting to grow laumontite from wairakite, Liou [1971] found that laumontite formed much more readily in solutions containing $\mathrm{NaCl}$ than in solutions of pure water. Measurements of water composition in the borehole through the Nojima fault [Ohtani et al., 2000] and at Cajon pass [Kharaka et al., 1988] indicate that $\mathrm{NaCl}$ is present in pore waters. Liou et al. [1991] state that while progressions from one zeolite mineral to another occur with depth, considerable overlap between zeolite species exist, and that this indicates that the formation of various zeolite minerals is controlled by more than pressure and temperature. Liou et al. [1991] state that formation of zeolites such as yugawaralite, stilbite, and laumontite may only be favorable in Ca-rich host rocks and that the concentration of quartz also influences the type of zeolite mineral that forms. Therefore, while laumontite is clearly associated with faults to a depth of $\sim 2.5 \mathrm{~km}$, it does not follow that laumontite is associated with faults at greater depth (i.e., 6-10 km). Finally, laumontite has also been found to precipitate in hot surface springs [Barnes et al., 1978], although, as Vincent and Ehlig [1988] point out, this laumontite is associated with gels and mineral assemblages that are not observed in association with fault-related laumontite.

[29] The presence of fluids in fault zones is well supported [e.g., Rice, 1992, and references therein]. Recently, Townend and Zoback [2000] suggested that faults and the surrounding fractured rocks are, in fact, the preferred migration paths for fluids in the crust. Byerlee [1993], Kennedy et al. [1997], and Faulkner and Rutter [2001] have argued that percolation of meteoric fluids, dehydration reactions or a mantle source are able to produce sufficient fluids to maintain elevated fluid pressure in fault zones, although a mechanism that confines fluids to the core of the fault zone remains enigmatic. The magnitude of fluid flow in the Punchbowl fault zone is unclear. Chester and Chester [1998] documented the presence of veins within the ultracataclasite elsewhere along the Punchbowl fault, indicating that fluids were present when the ultracataclasite formed. The changes in fault rocks relative to protolith documented in this study and others (keeping in mind that postfaulting neomineralization also occurred), and the existence of faultrelated mineralization indicate that fluids were present in the Punchbowl fault zone. This, however, does not necessarily indicate that the Punchbowl fault was weakened by elevated fluid pressure, unless the fluids were restricted to the fault core (i.e., the ultracataclasite), and this does not appear to hold in the case of the Punchbowl fault.

[30] The fabric intensity along the Punchbowl fault is weak, and is comparable to other fault gouge samples of variable clay content (Figure 9). The concentrations of phyllosilicates in the ultracataclasite is small, and the fabric is particularly poor, and since that is most likely the area where the majority of displacement was accommodated, it suggests that phyllosilicates did not significantly influence fault behavior through either changes in the mechanical properties or permeability structure of the fault. The poor phyllosilicate fabrics in these fault rocks indicate that fluids were not focused along the fault by preferentially oriented 


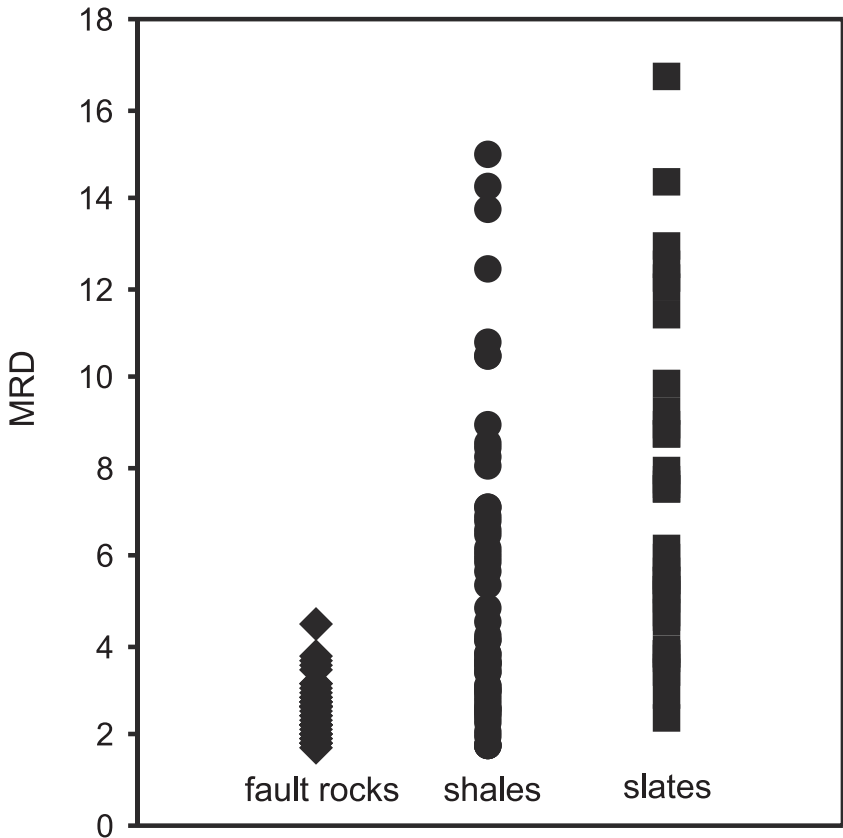

Figure 9. Phyllosilicate fabric intensities from a broad range of geologic settings. The average intensity in the Punchbowl fault is $3 \pm 1 \mathrm{MRD}$, which is in the range of values for other clay gouge samples and at the low end for a variety of foliated phyllosilicate-rich rocks. (data are from this study, Yan et al. [2001], J. Solum et al. unpublished data from the Moab and French faults, Ho et al. [1999, 1996, 2001], and Jacob et al. [2000]).

clay grains, except perhaps on a larger scale by clay shears in the banded cataclasite between the ultracataclasite and the sandstone/conglomerate.

\section{Conclusions}

[31] The Punchbowl fault, as an exhumed segment of the San Andreas fault system, provides the opportunity to study fault rock properties near the top of the seismogenic zone. The presence of limited clay growth during faulting indicates that clay mineralization was unimportant for the mechanical behavior of the fault. Substantial postfaulting mineralization occurred in the form of illite/dismectite, chlorite/trismectite, and zeolite growth, likely associated with exhumation.

[32] Combined XRD, XTG, SEM, and TEM analyses lead to the following sequence of mineralization. Formation of chlorite and group II chlorite/trismectite through neocrystallization and deformation of protolithic chlorite occurred during strike-slip faulting. This overlaps with formation of group II illite/smectite in the foliated cataclasite followed by group III chlorite/smectite in the ultracataclasite, followed by zeolite mineralization throughout the fault zone and extending into the protolith.

[33] Whereas fluids were present during strike-slip faulting, based on inferred mineral reactions, the poor phyllosilicate fabrics in fault rocks indicate that fluids were not preferentially focused along the fault zone by phyllosilicates, although it is possible that some focusing occurred through bands of coarse cataclasite bound by clay shears. The collective data indicate that phyllosilicate neomineralization and fluid focusing caused by clay fabrics did not dominate the mechanical properties, and so fault-weakening mechanism that appeal to elevated fluid pressure confined by clay fabric cannot be easily applied to the Punchbowl fault. In addition it is difficult to infer fault slip processes from exhumed fault zones because of postfaulting overprint. This highlights the need of collecting in situ samples from active faults rather than relying on exhumed segments, and the need for collecting samples from depths greater than previously examined drillholes.

[34] Acknowledgments. This study was funded through NSF grant EAR-9614407, a Grant-in-Aid from the American Association of Petroleum Geologists, and a grant from the Scott Turner Awards Program at the University of Michigan. TEM and SEM work were funded in part through NSF grants EAR-8917350 and EAR-9628196, respectively. Conversations with Larry Ruff on rupturing processes and Eric Essene on petrology are greatly appreciated. Reviews by Ann-Marie Boulier, Mark Zoback, and an anonymous reviewer greatly improved the manuscript.

\section{References}

Barnes, I., C. J. Downes, and J. R. Hulston, Warm Springs, South Island, New Zealand, and their potentials to yield laumontite, Am. J. Sci., 278, $1412-1427,1978$.

Beaufort, D., and A. Meunier, Saponite, corrensite, and chlorite-saponite mixed-layers in the Sancerre-Couy Deep Drill-Hole (France), Clay Miner., 29, 47-61, 1994.

Beaufort, D., A. Baronnet, B. Lanson, and A. Meunier, Corrensite: A single phase or mixed-layer phyllosilicate in the saponite-to-chlorite conversion series? A case study of Sancerre-Couy deep drill hole (France), Am. Mineral., 82, 109-124, 1997.

Byerlee, J., Model for episodic flow of high-pressure water in fault zones before earthquakes, Geology, 21, 303-306, 1993

Caine, J. S., J. P. Evans, and C. B. Forster, Fault zone architecture and permeability structure, Geology, 24, 1025-1028, 1996.

Chéry, J., M. D. Zoback, and R. Hassani, An integrated mechanical model of the San Andreas fault in central and northern California, J. Geophys. Res., 106, 22,051-22,066, 2001.

Chester, F. M., and J. S. Chester, Ultracataclasite structure and friction processes of the Punchbowl fault, San Andreas system, California, Tectonophysics, 295, 199-221, 1998.

Chester, F. M., and J. M. Logan, Implications for mechanical properties of brittle faults from observations of the Punchbowl Fault Zone, California, Pure Appl. Geophys., 124, 79-106, 1986.

Dibblee, T. W., Jr., Displacements on the San Andreas fault system in the San Gabriel, San Bernardino, and San Jacinto mountains, southern California, Stanford Univ. Publ. Geol. Sci., 11, 260-278, 1968

Dibblee, T. W., Jr., Geology of the Devil's Punchbowl, Los Angeles County, California, in Centennial Field Guide, edited by M. L. Hill, pp. 207-210, Cordilleran Sect., Geological Soc. of Am., Boulder, Colo., 1987.

Essene, E. J., and D. R. Peacor, Clay mineral thermometry-A critical perspective, Clays Clay Miner., 43, 540-553, 1995.

Evans, J. P., and F. M. Chester, Fluid-rock interaction in faults of the San Andreas system: Inferences from San Gabriel fault rock geochemistry and microstructures, J. Geophys. Res., 100, 13,007-13,020, 1995.

Evans, J. P., C.-B. Forster, and J.-V. Goddard, Permeability of fault-related rocks, and implications for hydraulic structure of fault zones, J. Struct. Geol., 19, 1393-1404, 1997.

Faulkner, D. R., and E. H. Rutter, Can the maintenance of overpressured fluids in large strike-slip fault zones explain their apparent weakness?, Geology, 29, 503-506, 2001

Henley, R. W., and A. J. Ellis, Geothermal systems ancient and modern: A geochemical review, Earth Sci. Rev., 19, 1-50, 1983.

Ho, N.-C., D. R. Peacor, and B. A. van der Pluijm, Contrasting roles of detrital and authigenic phyllosilicates during slaty cleavage development, J. Struct. Geol., 18, 615-623, 1996.

Ho, N.-C., D. R. Peacor, and B. A. van der Pluijm, Preferred orientation of phyllosilicates in Gulf Coast mudstones and relation to the smectite-illite transition, Clays Clay Miner., 47, 495-504, 1999.

Ho, N.-C., B. A. van der Pluijm, and D. R. Peacor, Static recrystallization and preferred orientation of phyllosilicates: Michigamme Formation, northern Michigan, USA, J. Struct. Geol., 23, 887-893, 2001. 
Hubbert, M. K., and W. W. Rubey, Role of fluid pressure in mechanics of over thrust faulting, Geol. Soc. Am. Bull., 70, 115-166, 1959.

Jacob, G., H. J. Kisch, and B. A. van der Pluijm, The relationship of phyllosilicate orientation, X-ray diffraction intensity ratios, and $\mathrm{c} / \mathrm{b}$ fissility ratios in metasedimentary rocks of the Helvetic zone of the Swiss Alps and the Caledonides of Jämtland, central western Sweden, J. Struct. Geol., 22, 245-258, 2000.

James, E. W., and L. T. Silver, Implications of zeolites and their zonation in the Cajon Pass Deep Drillhole, Geophys. Res. Lett., 15, 973-976, 1988.

Kanamori, H., and D. L. Anderson, Theoretical basis of some empirical relations in seismology, Bull. Seismol. Soc. Am., 65, 1073-1095, 1975.

Kennedy, B. M., Y. K. Kharaka, W. C. Evans, A. Ellwood, D. J. DePaolo, J. Thordsen, G. Ambats, and R. H. Mariner, Mantle fluids in the San Andreas fault system, California, Science, 278, 1278-1281, 1997.

Kharaka, Y. K., G. Ambats, W. Evans, and A. F. White, Geochemistry of water at Cajon Pass, California: Preliminary Results, Geophys. Res. Lett., $15,1037-1040,1988$.

Lachenbruch, A. H., and J. H. Sass, Heat flow and energetics of the San Andreas fault zone, J. Geophys. Res., 85, 6185-6222, 1980.

Lachenbruch, A. H., and J. H. Sass, The stress heat-flow paradox and thermal results from Cajon Pass, Geophys. Res. Lett., 15, 981-984, 1988

Liou, J. G., P-T stabilities of laumontite, wairakite, lawsonite, and related minerals in the system $\mathrm{CaAl}_{2} \mathrm{Si}_{2} \mathrm{O}_{8}-\mathrm{SiO}_{2}-\mathrm{H}_{2} \mathrm{O}$, J. Petrol., 12, 379-411, 1971.

Liou, J. G., C. DeCapitani, and M. Frey, Zeolite equilibria in the system $\mathrm{CaAl}_{2} \mathrm{Si}_{2} \mathrm{O}_{8}-\mathrm{NaAlSi}_{3} \mathrm{O}_{8}-\mathrm{SiO}_{2}-\mathrm{H}_{2} \mathrm{O}$, N. Z. J. Geol. Geophys., 34, $293-$ 301, 1991.

Melosh, H., Dynamical weakening of faults by acoustic fluidization, Nature, 379, 601-606, 1996.

Merriman, R. J., and D. R. Peacor, Very low-grade metapelites: Mineralogy, microfabrics and measuring reaction progress, in Low-Grade Metamorphism, edited by M. Frey and D. Robinson, pp. 313, Blackwell Sci., Malden, Mass., 1999.

Morrow, C. A., L. Q. Shi, and J. D. Byerlee, Permeability of fault gouge under confining pressure and shear stress, J. Geophys. Res., 89, 31933200, 1984.

Mount, V., and J. Suppe, State of stress near the San Andreas fault: Implications for wrench tectonics, Geology, 15, 1143-1146, 1987.

Ohtani, T., K. Fujimoto, H. Ito, H. Tanaka, N. Tomida, and T. Higuchi, Fault rocks and past to recent fluid characteristics from the borehole survey of the Nojima fault ruptured in the 1995 Kobe earthquake, southwest Japan, J. Geophys. Res., 105, 16,161-16,171, 2000.

Rice, J. R., Fault stress states, pore pressure distributions, and the weakness of the San Andreas Fault, in Fault Mechanics and Transport Properties of Rrocks; A Festschrift in Honor of W. F. Brace, edited by B. Evans and T.-F. Wong, pp. 475-503, Academic, San Diego, Calif., 1992.
Ruff, L. J., State of stress within the Earth, in IASPEI Handbook on Earthquake and Engineering Seismology, edited by W. Lee et al., pp. 539557, Academic, San Diego, Calif., 2002.

Scholz, C. H., The Mechanics of Earthquakes and Faulting, 439 pp., Cambridge Univ. Press, New York, 1990.

Scholz, C. H., Evidence for a strong San Andreas fault, Geology, 28, $163-$ $166,2000$.

Schulz, S. E., and J. P. Evans, Spatial variability in microscopic deformation and composition of the Punchbowl fault, southern California: Implications for mechanisms, fluid-rock interaction, and fault morphology, Tectonophysics, 295, 223-244, 1998.

Sibson, R. H., Conditions for fault-valve behaviour, in Deformation Mechanisms, Rheology and Tectonics, edited by R. J. Knipe and E. H. Rutter, Geol. Soc. Spec. Publ., 54, 15-28, 1990.

Townend, J., and M. D. Zoback, How faulting keeps the crust strong, Geology, 28, 399-402, 2000.

van der Pluijm, B. A., N.-C. Ho, and D. R. Peacor, High-resolution X-ray texture goniometry, J. Struct. Geol., 16, 1029-1032, 1994.

Vincent, M. W., and P. L. Ehlig, Laumontite mineralization in rocks exposed north of the San Andreas fault at Cajon Pass, southern California, Geophys. Res. Lett., 15, 977-980, 1988.

Wang, C.-Y., On the constitution of the San Andreas fault zone in central California, J. Geophys. Res., 89, 5858-5866, 1984.

Yan, Y., B. A. van der Pluijm, and D. R. Peacor, Deformation microfabrics of clay gouge, Lewis Thrust, Canada: A case for fault weakening from clay transformation, in The Nature and Tectonic Significance of Fault Zone Weakening, edited by R. E. Holdsworth et al., Geol. Soc. Spec. Publ., 186, 103-112, 2001.

Zen, Y., and A. B. Thompson, Low grade regional metamorphism: Mineral equilibrium relations, Annu. Rev. Earth Planet. Sci., 2, 197-212, 1974.

Zhang, S., and S. F. Cox, Enhancement of fluid permeability during shear deformation of a synthetic mud, J. Struct. Geol., 22, 13851393, 2000.

Zhang, S., T. E. Tullis, and V. J. Scruggs, Permeability anisotropy and pressure dependency of permeability in experimentally sheared gouge materials, J. Struct. Geol., 21, 795-806, 1999.

Zoback, M. D., Strength of the San Andreas fault, Nature, 405, 31-32, 2000 .

D. R. Peacor, J. G. Solum, and B. A. van der Pluijm, Dept. of Geological Sciences, Univ. of Michigan, 2534 CC Little Building, Ann Arbor, MI 48109-1063, USA. (jsolum@umich.edu)

L. N. Warr, Geologisch-Palaeontologisches Institut, Univ. of Heidelberg, Ruprecht-Karls-Univ. ät INF 234, D-69120 Heidelberg, Germany. 